\title{
Study of Serum Leptin in Children with Beta Thalassemia: Correlation with Iron Overload
}

\author{
EBTESAM R. ABD-ELKHALIK SELF, M.Sc.*; ADEL A. HAGAG, M.D.*; IBRAHIM M. BADRAIA, M.D.* and \\ MAALY M. MABROUK, M.D.** \\ The Departments of Pediatrics* and Clinical Pathology**, Faculty of Medicine, Tanta University
}

\begin{abstract}
Background: Beta thalassemia is a hereditary blood disorder with defective beta chain formation. $\beta$-thalassemia is a major public health problem in Egypt. Patients with multitransfused thalassemia develop severe endocrine complications due to iron overload.
\end{abstract}

Aim of the Work: Was to study serum leptin in children with beta thalassemia and its correlation with iron overload.

Subjects and Methods: The current study included 30 patients with beta thalassemia under treatment and follow-up in Hematology Unit, Pediatrics Department, Tanta University Hospital. All studied children were subjected to complete history taking, thorough clinical examination and laboratory investigations including complete blood count, serum iron, TIBC, serum glucose, serum ferritin and serum leptin using ELISA.

Results: There were significant differences between patients and control group as regard BMI and Tanner staging with delayed puberty according to Tanner staging and significantly lower BMI in patients compared with controls. Significantly higher levels of serum ferritin and serum iron and significantly lower TIBC were found in patients compared to control group. Serum leptin was significantly lower in patients than controls. There was significant positive correlation between serum leptin and age in studied patients and significantly higher serum leptin in female patients compared with males. Significant negative correlation was found between serum leptin and serum ferritin, but non-significant negative correlation between serum leptin and BMI.

Conclusion: Decreased serum leptin in $\beta$-thalassemia patients with significant positive correlation with age with higher levels in females compared to males. There is significant negative correlation between serum ferritin and serum leptin.

Key Words: Leptin - Iron overload - Thalassemia.

\section{Introduction}

$\boldsymbol{\beta}$-THALASSEMIA is an autosomal recessive disorder caused by defect in beta globin chain

Correspondence to: Dr. Ebtesam R. Abd-Elkhalik Self, The Department of Pediatrics, Faculty of Medicine, Tanta University synthesis of hemoglobin which is either complete absence of beta globin production or partial reduction of beta chain synthesis [1]

Thalassemia is prevalent in Mediterranean countries, the Middle East, central Asia, India, Southern China and the Far East as well as countries along the north coast of Africa and in South America. The highest carrier frequency is reported in Cyprus (14\%), Sardinia (10.3\%) and South East Asia [2] .

$\beta$-thalassemia is considered a very critical public health issue in Egypt. Being in continuity with other countries of the Mediterranean region, enhanced the genetic material to mix up with those of the native Egyptians [3]. The carrier rate of thalassemia varies between $5.3 \% \rightarrow 99 \%$, so it was estimated that 1000/1.5 million per year live birth born with thalassemia disease [4].

Repeated blood transfusions lead to iron overload in these patients. Excess iron can deposit in body organs particularly in pancreas, liver, pituitary, and the heart [5]

Leptin is a 167 amino acid peptide that is mainly expressed in white adipose tissue, but is also found in a variety of tissues including placenta, mammary gland, ovary, skeletal muscle, stomach, pituitary gland and lymphoid tissue [6].

Leptin regulates appetite, thermogenesis, hematopoiesis, angiogenesis, bone metabolism, reproduction and glucose homeostasis. Also it links nutritional status with neuroendocrine and immune function [7]

Six leptin receptor isoforms (LepRa-f) are known. These isoforms share a common leptin binding domains. LepRe uniquely lacks a transmembrane domain and is a soluble LepR isoform [8]. The leptin receptor is available on the bone 
marrow cells and hematopoietic stem cells. In hemolytic anemia such as $\beta$-thalassemia major this defect in the hematopoietic cells may lead to affected levels of leptin in these patients [9].

\section{Aim of the work:}

The aim of this work was to study serum leptin in children with beta thalassemia and its correlation with iron overload.

\section{Subjects and Methods}

This study was done after approval from ethical committee of research center of Tanta University and written consent from the parents of all children included in this study. The study was conducted on 30 thalassemic children under treatment and follow-up in Hematology Unit, Pediatrics Department, Tanta University in the period from June 2016 to May 2017 including 15 males and 15 females with their age ranged from 5 to 15 years and mean age value of $10.16 \pm 3.21$. This study included also 20 healthy children as a control group including 9 males and 11 females with their age ranged from 5 to 15 years and mean age value of $10.70 \pm 3.37$ years.

\section{Inclusion criteria:}

Children with beta thalassemia major.

\section{Exclusion criteria:}

Other types of chronic hemolytic anemia as sickle thalassemia, autoimmune hemolytic anemia, sickle cell anemia.

All the children in both groups were subjected to the following:

1- Full history taking with special emphasis on consanguinity between parents of patients with thalassemia and parents of controls, family history of thalassemia, age of diagnosis of thalassemia, frequency of blood transfusion and iron chelation therapy (types and regularity).

2- Clinical examination with special emphasis on pallor, jaundice, mongoloid facies, splenomegaly or splenectomy, hepatomegaly, cardiac manifestations, anthropometric measurements (weight, height, body mass index) and Tanner staging for assessment of puberty.

3- Investigations including:

- Complete blood count, $\mathrm{Hb}$ electrophoresis.

- Iron profile (serum iron, TIBC and serum ferritin).

- Serum glucose.

- Serum leptin.

\section{Specimen collection and handling:}

Seven $\mathrm{ml}$ venous pre-transfusion blood samples were collected at midnight from each patient by venipuncture under complete aseptic technique and were divided into four tubes as following:

One $\mathrm{ml}$ in a tube containing EDTA for $\mathrm{CBC}$ including differential WBCs and reticulocyte count which was done on Leishman stained peripheral blood smear with evaluation using ERMA PCE$210 \mathrm{~N}$ cell counter 10 , one $\mathrm{ml}$ was added to two $\mathrm{ml}$ hemolysate for $\mathrm{Hb}$ electrophoresis, three $\mathrm{ml}$ were collected in a plain tube and centrifuged for serum iron, total iron binding capacity 11 , serum ferritin using Accu Bind ELISA microwells from Monobind Inc 12 and serum glucose level which was done by using fully automated clinical chemistry auto-analyzer system 13 and two $\mathrm{ml}$ were collected in a plain tube, centrifuged and separated serums were stored at $20^{\circ} \mathrm{c}$ till assay for assessment of serum leptin. The DRG Leptin ELISA Kit is a solid phase enzyme-linked immunosorbent assay (ELISA) based on the sandwich principle 14. Samples were collected at midnight from nonfasting children.

Statistical analysis of the present study was conducted, using the mean, standard deviation and chi-square test by SPSS Version 17.

\section{Results}

Table (1) shows no significant difference between thalassemic patients and control group as regard age and sex, weight and height but significantly higher positive family history of thalassemia and positive consanguinity and significantly lower BMI in patients compared with control group with lower weight, height and BMI in patients compared with control group.

Table (2) shows that Pallor and jaundice were the most common presenting symptoms while hepatomegaly and splenomegaly were the most common presenting signs in studied patients.

Table (3) shows significant difference between patients and control group with delayed puberty in patients compared with control group.

Table (4) shows that microcytic hypochromic anemia with reticulocytosis was found in studied patients with significant differences in pre-transfusion complete blood count including hemoglobin level, reticulocytes, $\mathrm{MCV}, \mathrm{MCH}$, platelets and white blood cell count while non-significant difference as regard MCHC in patients compared with control group. 
There was significantly higher levels of serum ferritin and serum iron and significantly lower TIBC and serum leptin level in patients compared with control group.

There was significant positive correlation between serum leptin and age and significant negative correlation between serum leptin and serum ferritin in studied patients.

There was non-significant negative correlation between serum leptin and BMI of studied patients.

There was significantly higher serum leptin level in females compared to males.

Table (1): Demographic data, anthropometric measurements and Tanner staging of studied groups.

\begin{tabular}{|c|c|c|c|c|}
\hline \multirow{2}{*}{ Parameters } & \multicolumn{2}{|c|}{ Groups } & \multicolumn{2}{|c|}{$t$-Test or Chi-Square } \\
\hline & Patients $(n=30)$ & Controls $(n=20)$ & $t$ or $\mathrm{X}^{2}$ & $p$-value \\
\hline \multicolumn{5}{|l|}{ Age (Years): } \\
\hline Range & $5-15$ & $5-15$ & -0.563 & 0.576 \\
\hline Mean \pm SD & $10.167 \pm 3.217$ & $10.7 \pm 3.373$ & & \\
\hline \multicolumn{5}{|l|}{ Sex: } \\
\hline Male & $15(50 \%)$ & $9(45 \%)$ & 0.120 & 0.729 \\
\hline Female & $15(50 \%)$ & $11(55 \%)$ & & \\
\hline \multicolumn{5}{|c|}{ Family history of thalassemia: } \\
\hline Negative & $16(53.33 \%)$ & $20(100 \%)$ & 12.963 & $<0.001 *$ \\
\hline Positive & $14(46.67 \%)$ & $0(0 \%)$ & & \\
\hline \multicolumn{5}{|c|}{ Consanguinity between parents: } \\
\hline Negative & $6(20 \%)$ & $20(100 \%)$ & 30.769 & $<0.001 *$ \\
\hline Positive & $24(80 \%)$ & $0(0 \%)$ & & \\
\hline \multicolumn{5}{|l|}{ Weight (kg): } \\
\hline Range & $14-50$ & $17-62$ & -1.779 & 0.082 \\
\hline Mean \pm SD & $32 \pm 11.885$ & $38.65 \pm 14.431$ & & \\
\hline \multicolumn{5}{|l|}{ Height $(\mathrm{cm})$ : } \\
\hline Range & $105-153$ & $106-167$ & -1.018 & 0.314 \\
\hline Mean \pm SD & $133.667 \pm 15.548$ & $138.650 \pm 18.899$ & & \\
\hline \multicolumn{5}{|l|}{ BMI: } \\
\hline Range & $13.08-21.9$ & $15.1-22.6$ & -2.607 & $0.012 *$ \\
\hline Mean \pm SD & $17.080 \pm 2.915$ & $19.153 \pm 2.489$ & & \\
\hline
\end{tabular}

BMI = Body mass index.

Table (2): Clinical data in studied patients.

Table (3): Tanner staging in studied groups.

\begin{tabular}{|c|c|c|c|c|c|c|c|}
\hline Parameters & Patients $(n=30)$ & $\%$ & & \multirow{2}{*}{$\begin{array}{l}\text { Patients } \\
(\mathrm{n}=30)\end{array}$} & \multirow{2}{*}{$\begin{array}{l}\text { Controls } \\
(n=20)\end{array}$} & \multirow{2}{*}{$\mathrm{X}^{2}$} & \multirow{2}{*}{$\begin{array}{c}p- \\
\text { value }\end{array}$} \\
\hline Pallor & 27 & 90 & & & & & \\
\hline Jaundice & 13 & 43.33 & Tanner 1 & $16(53.33 \%)$ & $7(35 \%)$ & & \\
\hline Hepatomegaly & 26 & 86.67 & Tanner 2 & $8(26.26 \%)$ & $4(20 \%)$ & & \\
\hline Splenomegaly & 16 & 53.33 & Tanner 3 & $6(20 \%)$ & $1(5 \%)$ & 15.028 & $0.005^{*}$ \\
\hline Splenectomy & 14 & 46.67 & Tanner 4 & $0(0 \%)$ & $2(10 \%)$ & & \\
\hline Mongoloid facies & 12 & 40 & Tanner 5 & $0(0 \%)$ & $6(30 \%)$ & & \\
\hline
\end{tabular}


Table (4): Comparison between patients and controls as regard pre-transfusion complete blood count.

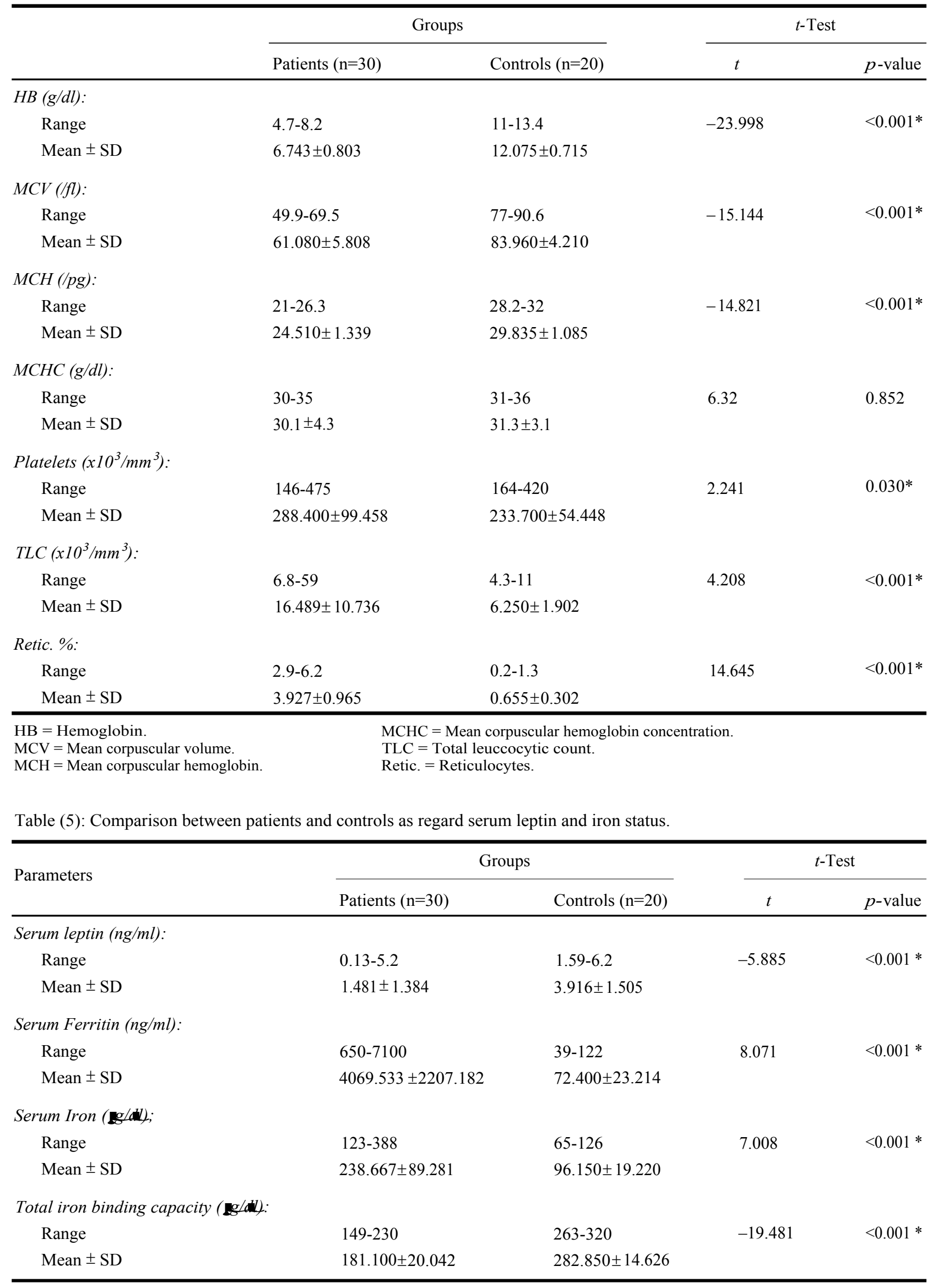



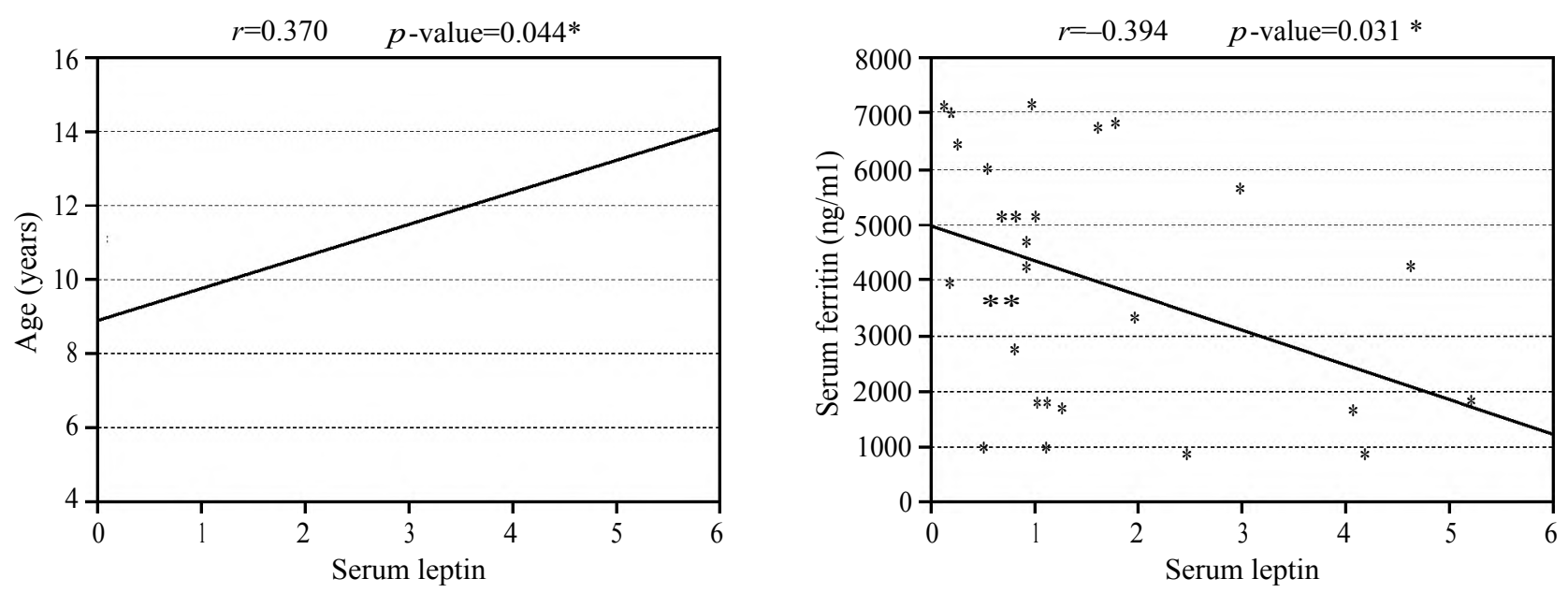

Fig. (1): Correlation between serum leptin and age (left) and serum leptin and serum ferritin (right) in studied patients.

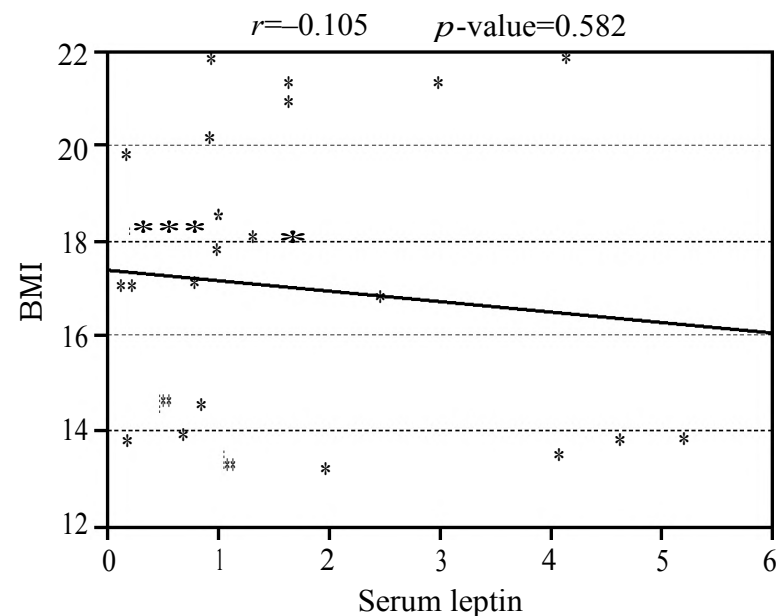

Fig. (2): Correlation between serum leptin and BMI in studied patients.

\section{Discussion}

Thalassemia results in severe anemia often requiring repeated blood transfusions. The fate of patients with transfusion-dependent thalassemia has improved substantially over the past 50 years. With the advent of regular transfusions, survival improved, but patients with thalassemia become iron overloaded [15]

Iron overload results in damage to the liver, endocrine organs, and most importantly to the heart without effective iron chelation, death occurs from cardiac failure or arrhythmia, usually in late childhood or in the teenage years [16]

Leptin is a polypeptide hormone which is mainly expressed in white adipose tissue [6]. The leptin receptor is available on the bone marrow cells, hematopoietic and stem cells [9].

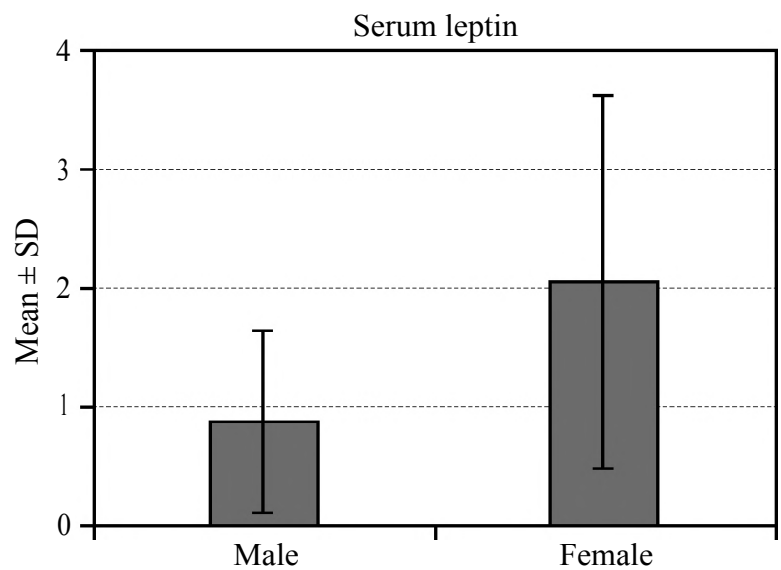

Fig. (3): Relation between serum leptin and sex in studied patients.

The aim of the present work was to study serum leptin level in patients with beta thalassemia and its correlation with iron overload.

This study was carried out on 30 children with $\beta$-thalassemia major who were under treatment and follow-up in Hematology Unit, Pediatric Department, Tanta University Hospital and 20 healthy children as a control group.

In the present study, pallor and jaundice were the most common presenting symptoms in thalassemic patients, while hepatomegaly and splenomegaly were the most common signs. This is in agreement with Hagag et al. [17] who found the same results. This could be explained by chronic hemolysis, extramedullary erythropoiesis and iron overload as stated by Galanello and Origa [18] or hemosiderosis, extra medullary hematopoiesis, transmitted hepatitis $\mathrm{B}$ and $\mathrm{C}$ with subsequent cirrhosis as stated by Hashemizadeh et al. [19] 
In the present study, there was significantly lower body mass index in patients compared with control group. This is in agreement with Eissa and El-Gamal [20] who explained low BMI in thalassemic children by chronic nature of the disease. As physical growth is affected in transfusiondependent thalassemic patients, minimizing the iron overload in these patients should be warranted for them to have normal growth and development.

In the present study, there was microcytic hypochromic anemia with reticulocytosis with significantly lower $\mathrm{Hb}, \mathrm{MCV}$ and $\mathrm{MCH}$ and significantly higher reticulocytes \% in thalassemic patients compared with control group. This is in agreement with Mahmoud et al. [21], Winichagoon et al. [22] who demonstrated that decreased hemoglobinization of red cells resulting in hypochromia and microcytosis which are the main features of thalassemia syndromes and El-Shanshory et al. [3] who found reticulocytosis in thalassemic patients which could be explained by hemolytic nature of the disease causing hyperactive bone marrow with subsequently reticulocytosis.

In this study, there were significantly higher leucocytic and platelets counts in patients compared with control group. This is in agreement with ElGammal et al. [23] and Fayed et al. [24]

In this study, there were significantly higher serum ferritin and serum iron and significantly lower serum total iron binding capacity in studied patients compared with controls which could be explained by frequent packed RBCs transfusion and irregular iron chelators intake. This is in agreement with Nasr et al. [20], Eissa and El-Gamal [25], Faruqi et al. [26] and Hagag et al. [27] who found the same results. Iron overload in beta thalassemia could be explained by two main mechanisms, increased iron absorption due to ineffective erythropoiesis and repeated blood transfusion [28] .

In the present study, there was significantly lower serum leptin in patients compared to control group. This is in agreement with Shahramian et al. [9] who studied 45 cases of thalassemia children and stated that, serum leptin levels were significantly lower than normal participants, Choobineh et al. [29], Karami et al. [30] and Elsayh et al. [31] who found significantly lower serum leptin level in patients compared with control group. In fact, iron overload followed by iron deposition in fat cells can lead to toxic effects of iron which is the result of free radical formation and inhibits the activity of adiposities leading to destruction of the fat cell membrane and dysfunction in adipose tissue [18].
In the present study, there was delayed puberty as regard Tanner staging in studied patients compared with control group. This is in agreement with Hagag et al. [27] who found delayed puberty in patients with beta thalassemia major, Sayed et al. [32] who found the same results and revealed a decrease in serum leptin level together with delayed pubertal development in patients with betathalassemia major which may be due to the effect of iron overload on endocrinal glands and adipose tissue. The low serum leptin level might be a contributing factor for delayed puberty reported in beta thalassemia major patients and Kyriakou and Skordis [33] who stated that delayed puberty and hypogonadism are the most common endocrine complications in patients with thalassemia major.

In the present study, there was significant positive correlation between serum leptin level and age of the studied patients in which serum leptin level increase with age. Shahramian et al. [34] found the same results and demonstrated that since from the age of 10 years the cardiac involvement begins to increase, so there is a remarkable and positive association between leptin and cardiac involvement, but Shahramian et al. [9] found no significant relationship between leptin and age as increase of age could not result in an increase of fat mass as well as leptin production.

In the present study, there was significant relation between serum leptin and sex with higher leptin level in females than males. This is in agreement with Choobineh et al. [29], Shahramian et al. [9] and Al-Naama et al. [35] who found significantly higher serum leptin in females with beta thalassemia major compared with males with the same disease. Androgens are thought to provoke a reduction in leptin production, which may explain the low levels of serum leptin observed in male individuals. However, factors other than sex steroid hormones (e.g., fat mass in the body and energy expenditure) may cause a fluctuation in serum leptin concentrations [35]. Also lower levels of leptin in males may be explained by lesser mRNA expression of leptin in males compared to females [36]

In the present study, there was significant negative correlation between serum leptin level and serum ferritin of the studied patients. This is in agreement with Chaliasos et al. [37], Shahramian et al. [9] and El-Rasheidy et al. [38] who found significant negative correlation between the serum levels of leptin and ferritin in children with $\beta$ thalassemia major.

In fact, iron overload in fat cells can lead to free radical formation and inhibits the activity of 
adipose tissue. Along with the destruction of the fat cell membrane and the dysfunction in adipose tissue, it leads to a decrease in serum leptin level [9].

It seems that adipose cells of thalassemia patients are not able to produce adequate leptin which might be due to deposition of iron in these cells. Therefore, the defect in adipose tissue function in thalassemic patients can be considered as an endocrine system dysfunction, although it seems other factors may interfere in the decrease of serum leptin level in thalassemic patients. As a patient is more underweight with less fat tissue so the ability to produce leptin would be lower [39].

\section{Conclusion:}

Decreased serum leptin in $\beta$-thalassemia patients with significant positive correlation with age with higher levels in females compared to males. There is significant negative correlation between serum ferritin and serum leptin.

\section{Acknowledgements:}

This research was carried out without funding.

\section{Conflicts of interest:}

No conflicts of interest declared.

\section{Authors contributions:}

All authors had equal role in design, work, statistical analysis and manuscript writing. All authors have approved the final article work.

\section{References}

1- SUMAN R.L., SANADHYA A., MEENA P., SINGH J., JAIN R. and MEENA S.: Lipid profile in children of $\beta$ thalassemia major and their correlation with serum ferritin. International Journal of Contemporary Pediatrics, 4 (2): 543-7, 2017.

2- TAHER A.T., CAPPELLINI M.D. and MUSALLAM K.M.: Recent advances and treatment challenges in patients with non-transfusion-dependent thalassemia. Blood reviews, 26: S1-2, 2012.

3- EL-SHANSHORY M.R., HAGAG A.A., SHEBL S.S., BADRIA I.M., ABD ELHAMEED A.H., ABD EL-BAR E.S., et al.: Spectrum of beta globin gene mutations in Egyptian children with $\beta$-Thalassemia. Mediterranean Journal of Hematology and Infectious Diseases, 6 (1): e2014071, 2014.

4- EL-BESHLAWY A. and YOUSSRY I.: Prevention of hemoglobinopathies in Egypt. Hemoglobin, 33 (1): 1420, 2009.

5- BAYANZAY K. and ALZOEBIE L.: Reducing the iron burden and improving survival in transfusion-dependent thalassemia patients: Current perspectives. Journal of Blood Medicine, 7: 159-69, 2016.
6- PARK H.K. and AHIMA R.S.: Physiology of leptin: energy homeostasis, neuroendocrine function and metabolism. Metabolism, 64 (1): 24-34, 2015.

7- PROCACCINI C., La ROCCA C., CARBONE F., De ROSA V., GALGANI M. and MATARESE G.: Leptin as immune mediator: Interaction between neuroendocrine and immune system. Developmental \& Comparative Immunology, 66: 120-9, 2017.

8- MÜNZBERG H. and MORRISON C.D.: Structure, production and signaling of leptin. Metabolism, 64 (1): 1323, 2015.

9- SHAHRAMIAN I., AKHLAGHI E., RAMEZANI A., REZAEE A., NOORI N. and SHARAFI E.: A study of leptin serum concentrations in patients with major betathalassemia. Iranian Journal of Pediatric Hematology and Oncology, 3 (2): 59-63, 2013.

10- MONICA C.: Strategy of blood safety in Africa region. In Tito A. and Lewis S.M. (eds). District laboratory practice in tropical countries, 2 nd edition. Cambridge low price Egyptian edition, Chapter 4: 268-378, 2005.

11- WEISSMAN N.P. and LEGGI V.J.: Principles and techniques. In: Henry R.J., Cannon D.C., Winkelmen J.W. (eds). Clinical chemistry, 2 nd edition. Harber and Row, 692-3, 1974.

12-NAIMARK B.J., READY A.E., SAWATZKY J.A., BORESKIE S., DUCAS J., DRINKWATER D.T., et al.: Serum ferritin and heart disease: The effect of moderate exercise on stored iron levels in postmenopausal women. The Canadian Journal of Cardiology, 12 (12): 1253-7, 1996.

13- TIETZ N.W.: Clinical guide to laboratory tests. ${ }^{3^{\text {rd }}}$ ed. Philadelphia: WB Saunders, 2: 268-273, 1995.

14- GUILLAUME M. and BJÖRNTORP P.: Obesity in children. Hormone and Metabolic Research, 28 (11): 573-81, 1996.

15- COATES T.D., CARSON S., WOOD J.C. and BERDOU KAS V.: Management of iron overload in hemoglobinopathies: what is the appropriate target iron level?.Annals of the New York Academy of Sciences, 1368 (1): 95-106, 2016.

16- HOFFBRAND A.V., TAHER A. and CAPPELLINI M.D.: How I treat transfusional iron overload. Blood, 120 (18): 3657-69, 2012.

17- HAGAG A.A., ELFRARGY M.S., GAZAR R.A. and ELLATEEF A.E.: Therapeutic value of combined therapy with deferasirox and silymarin on iron overload in children with Beta thalassemia. Mediterr J. Hematol. Infect Dis., 5: e2013065, 2013.

18- GALANELLO R. and ORIGA R.: Beta-thalassemia. Orphanet Journal of Rare Diseases, 5 (1): 11, 2010.

19-HASHEMIZADEH H., NOORI R.: Assessment hepatomegaly and liver enzymes in 100 patients with beta thalassemia major in Mashhad, Iran. Iranian Journal of Pediatric Hematology and Oncology, 2 (4): 171-7, 2012.

20- EISSA D.S. and EL-GAMAL R.A.: Iron overload in transfusion-dependent $\beta$-thalassemia patients: Defining parameters of comorbidities. The Egyptian Journal of Haematology, 39 (3): 164-70, 2014.

21- MAHMOUD S.S., MOHAMED G.B., HAKEEM G.L.A., HIGAZI A.M., NAFADY A.A.H., FARAG N.M., et al. 
Comparison of the Immunity Status In-between Children with $\beta$-Thalassaemia Major Receiving Different Treatment Modalities: A Single Egyptian District Study. Immunome Res., 13 (1): 1-8, 2017.

22- WINICHAGOON P., KUMBUNLUE R., SIRANKAPRACHA P., BOONMONGKOL P. and FUCHAROEN S.: Discrimination of various thalassemia syndromes and iron deficiency and utilization of reticulocyte measurements in monitoring response to iron therapy. Blood Cells, Molecules and Diseases, 54 (4): 336-41, 2015.

23- ELGAMMAL M., MOURAD Z., SADEK N., ABASSY H. and IBRAHIM H.: Plasma levels of soluble endothelial protein $C$-receptor in patients with $\beta$-thalassemia. Alexandria Journal of Medicine, 48 (4): 283-8, 2012.

24- FAYED M.A., ABDEL-HADY H.E.S., HAFEZ M.M., SALAMA O.S. and AL-TONBARY Y.A.: Study of Platelet Activation, Hypercoagulable State, and the Association with Pulmonary Hypertension in Children with $\beta$ Thalassemia. Hematology/Oncology and Stem Cell Therapy, http://dx.doi.org/10.1016/j.hemonc.2017.05.028, 2017.

25- NASR M.R., EBRAHIM N.A. and SALAHEDIN O.: Growth pattern in children with beta-thalassemia major and its relation with serum ferritin, IGF1 and IGFBP3. Journal of Clinical and Experimental Investigations, 3 (2): 157-63, 2012.

26- FARUQI A., AMJAD S., SAMI A.N., HASSAN S. and ZIA Q.A.: Electrocardiographic Changes in Thalassemia Major Patients and their Association with Serum Ferritin Levels. Journal of Rawalpindi Medical College, 19 (3): 185-8, 2015.

27- HAGAG A.A., BADRAIA I.M., ELFARARGY M.S. and ABO EL-ENEIN A.M.: Study of male sex hormone levels in male Egyptian children with beta-thalassemia: Correlation with iron load. Endocrine, Metabolic \& Immune Disorders-Drug Targets, 16 (2): 124-130, 2016.

28- BHAGAT S.S., SARKAR P.D., SURYAKAR A.N., GHONE R.A. and PADALKAR R.K.: Special effects of oral therapeutic supplementation of antioxidants on attenuation of iron overload in homozygous beta thalassemia. Int. J. Health Sci. Res., 2: 36-41, 2012.

29- CHOOBINEH H., DEHGHANI S.J., ALIZADEH S., DANA V.G. and SAIEPOUR N.: Evaluation of leptin levels in major beta-thalassemic patients. International Journal of Hematology-Oncology and Stem Cell Research, 3 (4): 1-4, 2009.
30- KARAMI H., KOWSARIAN M., KOWSARIAN S.A., MAHDAVI M.R., DANESHMANDI Z., KHADEMLOO M., et al.: The Relationship Between Developing Thalassemia Major and Dysfunction of Pancreatic Endocrine and Exocrine. Journal of Mazandaran University of Medical Sciences, 21 (83): 2-7, 2011.

31- ELSAYH K.I., MOHAMMED W.S., ZAHRAN A.M. and SAAD K.: Leukocytes apoptosis and adipocytokines in children with beta thalassemia major. Clinical and Experimental Medicine, 16 (3): 345-50, 2016.

32- SAYED S.Z., ABOUL-FOTOH L.E., EL-SAGHIR A.I. and EL-HAK L.H.: Serum Levels of Gonadotrophins and Leptin in Patients with B-Thalassemia Major. Journal of Arab Child, 24 (1): 83-90, 2013.

33- KYRIAKOU A. and SKORDIS N.: Thalassaemia and aberrations of growth and puberty. Mediterranean Journal of Hematology and Infectious Diseases, 1 (1): 2035-3006, 2009.

34- SHAHRAMIAN I., NOORI N.M., TEIMOURI A., AKHLAGHI E. and SHARAFI E.: The correlation between serum level of leptin and troponin in children with major beta-Thalassemia. Iranian Journal of Pediatric Hematology and Oncology, 5 (1): 11, 2015.

35- AL-NAAMA L.M., HASSAN M.K. and ABDUL KARIM M.M.: Evaluation of Serum Leptin Levels and Growth in Patients with $\beta$-Thalassaemia Major. Anemia 2016; Article ID 8454286, doi:10.1155/2016/8454286, 2016.

36- DEDOUSSIS G.V., KYRTSONIS M.C., ANDRIKOPOULOS N.E., VOSKARIDOU E. and LOUTRADIS A.: Inverse correlation of plasma leptin and soluble transferrin receptor levels in beta-thalassemia patients. Ann. Hematol., 81 (9): 543-7, 2002.

37- CHALIASOS N., CHALLA A., HATZIMICHAEL E., KOUTSOUKA F., BOURANTAS D.K., VLAHOS A.P., et al.: Serum adipocytokine and vascular inflammation marker levels in Beta-thalassaemia major patients. Acta. Haematologica, 124 (4): 191-6, 2010.

38- EL-RASHEIDY F.H., ESSA E.S., MAHMOUD A.A. and LASHEEN A.T.: Effect of abnormalities in leptin levels on pituitary-hypothalamic axis in patients with chronic hemolytic anemia. Menoufia Medical Journal, 30 (3): 770-7, 2017.

39- KARAMIFAR H., BAHMANYAR M. and KARIMI M.: Study of Serum Leptin and Ghrelin Levels in Thalassemia Major. ISMJ, 13 (2): 86-92, 2010. 


\section{دراسة مستوى اللبتين فى الأطفال المرضى بانيميا البحر المتوسط

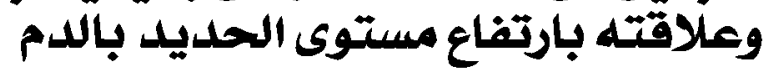

البيتا ثلاسيميا هى أحد الإراض الوداثية التى يمكن تعريفها على نطاق واسع بإعتبارها متلازمة إضطرابات الهيموجلوبين المورثه والتى

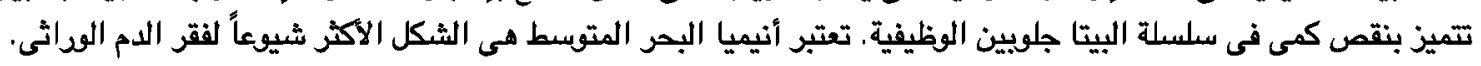

الهدف من البحث: هو دراسة مستوى اللبتين فى الأطفال المرضى بأنيميا البحر المتوبط وعلاقته بارتفاع مستوى الحديد بالدم.

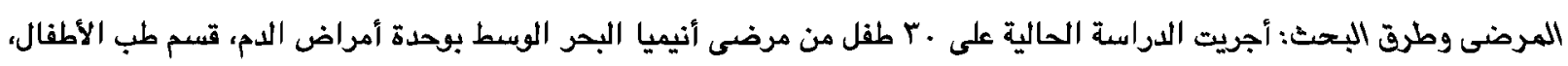

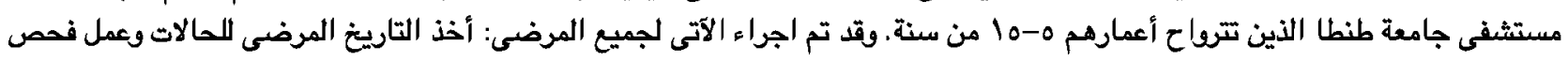

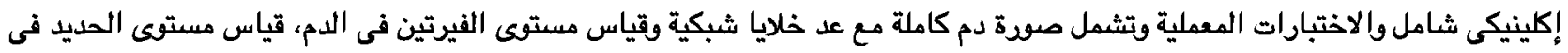

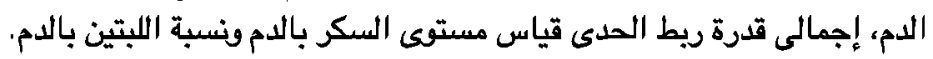

النتائج: انخفاض مستوى اللبتين وتأخر فى البلوغ فى مرضى انيميا البحر المتوسط عن مجموعة الأصحاء ووجود علاقة طردية بينه وبين

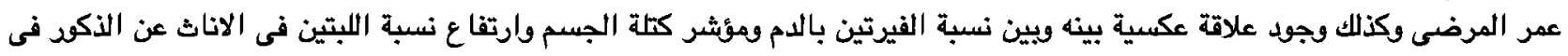
مجموعة المرضى.

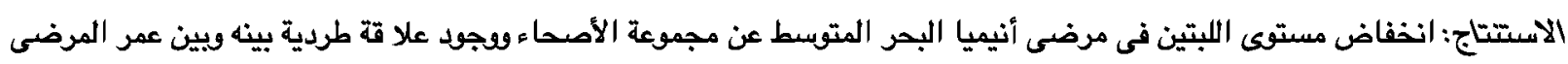

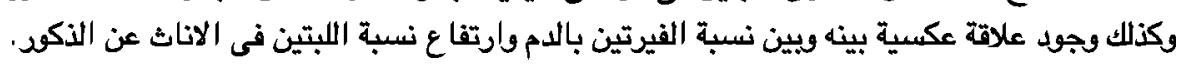
التوصيات: نوصى بالمتابعة المستمرة لمرضى أنيميا البحر المتوسط بالنسبة لانتظام نقل الدم وتتاول مزيلات الحديد بجرعات وطرق سليمة

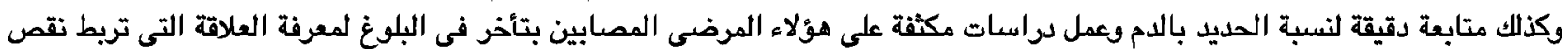
اللبتين بتأخر البلوغ. 